\title{
Peace Education Model Based on the Piramid Model to Reach Forgiveness to Increase Resilience Tobullying Victims in the Digital Era
}

\author{
Tristiadi Ardi Ardani' ${ }^{1}$, Fattah Hanurawan ${ }^{2}$, Carolina L.Radjah ${ }^{3}$, Triyono ${ }^{4}$ \\ ${ }^{1,3,4}$ Program Studi Bimbingan dan Konseling, Universitas Negeri Malang, Indonesia. Faculty of Psychology of the State Islamic \\ University ( UIN ) Maulana Malik Ibrahim Malang, Indonesia \\ ${ }^{2}$ Fakultas Pendidikan Psikologi (FPPsi), Universitas Negeri Malang, Indonesia \\ ${ }^{1}$ tristiadiardiardani@psi.uin-malang.ac.id, ${ }^{2}$ fattah.hanurawan.fppsi@um.ac.id
}

\begin{abstract}
The aim of this article is to develop a forgiveness-based peace education model to increase resilience. Peace Education is the process of obtaining values, knowledge and developing attitudes, skills and behavior to live in harmony with oneself, with others, and with the natural environment. In a positive psychology perspective, forgiveness is an effort to become an afterthought and practice to reconcile the soul in the digital era. While resilience is an individual's ability to remain able to survive and remain psychologically stable and healthy after going through traumatic events. Meanwhile, this research method uses a development research design approach. Gay (1990) The research and development design approach method is a research procedure that produces a product that is effective for use at both the university learning level and school learning. The design of research and development designs through the exploratory and experimental stages. The explorative stage with a quantitative approachwith a survey method to analyze the problem. While the experimental stage uses experimental stages in existing research.
\end{abstract}

Keywords

Peace Education, Forgiveness; Resilience, Bullying

Article Received: 10 August 2020, Revised: 25 October 2020, Accepted: 18 November 2020

\section{Introduction}

Peace Education is the process of obtaining values, knowledge and developing attitudes, skills and behavior to live in harmony with oneself, with others, and with the natural environment. The concept of forgiveness turns out to have enormous implications for the lives of the people. So that forgiveness becomes a topic in itself that is included in the realm of positive psychology which is a relatively new school of psychology in the development of psychology. The birth of this psychology brought fresh air to the development of Western psychology, which has spent its time discussing negative issues, around human pathology. Positive Psychology offers a new way to see humans no longer focus on treating illness and seeing someone's shortcomings but moving on by seeing the potential and strengths possessed by individuals.

Forgiveness then directly affects physical health and resilience by reducing levels of hostility, enhancing the cellular and neuro-endocrine immune system, releasing antibodies, and influencing processes in the central nervous

system. Several figures who paid attention to the theory of forgiveness are Thomson, McCullough, Enright, and Tangney. All of these characters have their own definition of forgiveness. McCullough defines forgiveness as a series of changes in motivation, namely from the motivation for revenge to decrease, the motivation to avoid meeting the perpetrator decreases and the motivation to act peacefully increases.

Thompson in C.R. Snyder el. at. (2011) defines forgiveness as an attempt to place a violation event that is felt by a person, a person's response to the perpetrator, events, and the consequences of the events experienced are changed from negative to neutral or positive. Forgiveness can occur in three things, namely forgiveness for others, yourself and for conditions, namely forgiving situations that cause negative feelings to arise in him, for example disasters and others. Enright (2002), says forgiveness is someone's willingness to leave anger and negative assessments of people 
who have hurt them. Repay him with compassion and love and generosity.

Resilience or resilience has the literal meaning of resilience, resilience or joy. The term resilience was first formulated by Block with the name egoresillience, which is defined as a general ability that involves a high ability to adjust and be flexible when faced with internal and external pressures.

\section{Research And Development Objectives And Methods}

Overall, the purpose of this research is to provide a perspective of forgiveness-based peace education to increase risk in the digital era and the era of the fourth industrial revolution. While this research method with a development research design approach. Gay (1990) The research and development design approach method is a research procedure that produces a product that is effective for use at both the university learning level and school learning.

The purpose and solution of the problem can be given after the presentation of the concept of forgiveness in positive psychology. Empirically, researchers see how forgiveness is empirically carried out by psychologists in the study of positive psychology. In the view of positive psychology, solutions will be found for various problems in the field, namely the academic anxiety of researchers, namely high levels of fighting, stress and increasing levels of frustration. The form of solution referred to is given in the form of forgiveness-based peace education to increase resilience.

The design of research and development designs through the exploratory and experimental stages. The explorative stage with a quantitative approach with a survey method to analyze the problem. While the experimental stage uses experimental stages.

\section{Forgiveness In The Concept Of Positive Psychology}

The theory of forgiveness in positive psychology can be found in the thoughts of several figures. Enright gives a definition to forgiveness as an attitude of forgiveness to someone who has not greeted with a reply but reciprocated with generosity and compassion. This is the meaning of forgiveness according to him. Meanwhile Hughes (1975) sees forgiveness as a method used to improve social harmony in a community environment. The same thing was also conveyed by McCullought that forgiveness can be used as motivation to change someone to not take revenge and reduce the urge to stay away or keep a distance from the person who has done the hurt. By forgiving will also generate an urge to make peace and behave well towards people who make mistakes. Thus the purpose of forgiveness for them is an effort to maintain good relationships with others. Paying attention to some of the definitions given by the characters about forgiveness has no significant difference. Philpot, $\mathrm{C}$ in a book that has been compiled by the American Psychology Association collects several opinions from the figures about forgiveness. So the conclusion can be obtained states that forgiveness occurs when a person realizes that he is in a position of being hurt and he feels he should get better treatment. Furthermore, this forgiveness is a process of changing emotions in attitude towards people who have hurt them. Regarding the opinion that forgiveness is a change or transition from negative emotions to positive emotions in treating the perpetrator with affection, we still do not agree to what extent this can happen. To see the extent to which experts see efforts to do good to the perpetrators, it can be traced to the stages they have compiled about forgiveness.

Experts provide various ways to make stages to arrive at this forgiveness stage by someone who has been hurt. From several figures who studied it, the author only took two samples within the framework of this theory, namely Enright (1998) and Worthington. Enright and Coyle developed a model for the forgiveness stages. This model includes cognitive, affective and behavioral aspects that occur in the forgiveness process. The forgivenees in this model are divided into four phases. The first phase is called the Uncovering 
Phase. This is the first process in which a person needs to be aware of and feel the negative emotions he is feeling. Furthermore, the second phase is Desicion Phase, where the sufferer has a commitment to forgive the perpetrator. In this phase, the feeling of revenge for revenge is eliminated.

The third phase is the Work Phase, where the individual can forgive the offender by empathizing. The individual puts his position in the position of the offender who must feel uncomfortable after making a mistake. In this phase the individual chooses to offer some good deeds. The fourth phase is the Outcome / Deeping Phase where the individual consciously feels healed and recovered and has positive emotions because he has done forgiveness. Thus, the stages arranged by Elright look simple and like the therapeutic efforts carried out by therapists today in releasing negative feelings from the past by reviving memories in his subconscious.

The next character who compiles the Forgiveness stages isWorthington (1998). The theory used here is known as the pyramid model to REACH forgiveness. At first glance, this theory is almost the same as Enright's theory, except that Worthington divides the process into five stages. Namely, Recall the hurt means that the individual will recall pain due to the incident that hurt him. Individual empathy tries to find the causes why the perpetrator is bad at him and puts himself in the position of the perpetrator. The alturistic gift of an individual tries to remember that he also made mistakes and then other people forgive him sincerely, so that he feels worthy to forgive others. Commit Publicly to forgive, this stage the individual already has a commitment to forgive someone's mistakes and tries not to remember the incident on purpose. While slowly trying to forget it. Hold on forgiveness, at this stage the effort to forgive is actually felt to be perfect, but individuals are trying to be able to maintain it. The individual tries to feel and make sense of the benefits he gets after forgiving the offender who has hurt him.

\section{Peace Education In The Digital Age}

Peace Education, Forgiveness; Resilience, BullyingPeace Education is the process of obtaining values, knowledge and developing attitudes, skills and behavior to live in harmony with oneself, with others, and with the natural environment. Paying attention to the phases of forgiveness in positive psychology, it seems that it requires several stages and stages by stage it takes time and requires tarapis that can help someone heal their hurt because of someone's negative treatment. This is clearly very different from the teachings in Islam where forgiveness can be given immediately and without the intermediary of another human being. This is because forgiveness given to others has a strong bond and relationship with divine values.

Referring to the character education delivered by Thomas Lichona, character education includes knowing, feeling and doing. The same can apply to educating children to be able to forgive others and also forgive themselves. Likewise for adults this effort can also be done by looking at forgiveness in the applicable realm not only in the realm of normative knowledge. Talking about empirical things about forgiveness we can see how forgiveness is in positive psychology.

But the function of giving forgiveness to others is to provide peace in the human soul. This is because the human instinct always wants to do good, that man has a divine nature in his soul besides having a human nature. Divine value will appear more when humans do good and eliminate the badness in their hearts. So that someone will get calm and happiness when he is able to forgive others. Furthermore, whether everyone has the same ability in an effort to forgive the mistakes of others against him. Before looking at how to increase one's ability to be able to easily apologize to others, it is necessary to look at some of the reasons that influence someone to give will to others.

Things that influence someone in giving forgiveness include empathy, assessment of others, the level of one's injury, the characteristics of a person's personality, the quality of interpersonal relationships, the quality of apology, and one's social cognitive conditions. Based on 
these factors, some solution can be taken to train someone, especially students or students to grow into forgiving individuals. The first is the need to cultivate a child's sense of empathy for others, to get children to feel the suffering of others. In real terms, educators can bring children to places where they can touch their social sensitivity, such as conducting school visits to orphanages and special schools. Besides that, it can also activate the sharing program, once a month the children are invited to share with the less fortunate and those who need help.

Second, get children to think positively, provide and instill the value of Husnul Zhan in others. That everyone actually wants to do good as well as himself and that every good deed always has wisdom and kindness in return. The method that can be used is through giving paper assignments to adolescent students and for elementary class students by telling stories and explorations. Third, one's interpersonal relationships can be improved by inviting students to frequently discuss and interact with other people. This is a tough challenge in the digital era because most children and even adults are busy with their own gadgets. They grew up to be individualists and more introverted. The task of educators is to present various activities that make them active and get involved in activities together. Giving group work assignments and discussing in groups and outside the group is one way that teachers can take it.

Resilience is a person's capacity to respond healthily and productively when faced with adversity or trauma, which is needed to manage the pressures of daily life or the ability to adapt and remain resilient in difficult situations. Reivich and Shatte (2002)

The following is the definition of resilience according to several psychologists, Resilience as the capacity or ability to adapt positively in overcoming significant life problems. R-G Reed Resilience is a psychological construct proposed by behavioral experts in an effort to identify, define and measure an individual's capacity to survive and develop in adverse conditions and to determine an individual's ability to recover from stressful conditions. McCubbin (2001) Resilience is an individual's ability to remain able to survive and remain psychologically stable and healthy after going through traumatic events. Samuel Resilience is the ability to adapt positively when conditions are unpleasant and full of risks. Nurinayanti and Atiudina (2011).Resilience is the presence or presence of good outcomes (good results) and the ability to overcome threats in order to support the individual's ability to adapt and develop positively. Roberts (2007)

Resilience is a capacity that is universal and with that capacity, individuals, groups or communities are able to prevent or minimize or resist damaging influences when they experience disaster or adversity. According to him, resilience is also influenced by many factors, including external support, personal strength that develops in a person and social abilities. Gotberg. Resilience is an attitude (trait). This trait is a hidden capacity that arises to fight individual destruction and protect individuals from all the obstacles of life. Individuals who have good intelligence, adaptability, social temperament, and have an attractive personality end up contributing consistently to self-respect, competence and the feeling that they are lucky. These individuals are resilient individuals. Wolff. According to Emmy E Wenner, a number of behavioral experts use the term resilience to describe three phenomena, namely:. Positive developments that result from children living in "high-risk" contexts, such as children living in chronic poverty or abuse by their parents. The possible competencies emerged under prolonged stress, such as the events surrounding their parents' divorce; and healing from trauma, such as fears from civil war events and concentration camps.

\section{Characteristics of Individuals with Resilience Ability}

According to Wolin and Wolin (1999), there are seven main characteristics possessed by resilient individuals. These characteristics make individuals able to adapt well when facing problems, overcome various obstacles, and develop their potential to the maximum, namely: a. Insight 
Insight is the mental ability to ask yourself questions and answer honestly. This is to help individuals to be able to understand themselves and others, and be able to adjust to various situations.

b. Independence

Independence is the ability to distance yourself emotionally and physically from the source of problems in one's life. Independence involves being able to maintain a balance between being true to yourself and caring for others.

c. Relationship

A resilient person can develop honest, mutually supportive and quality relationships for life, or have a healthy role model.

d. Initiative

Initiative involves a strong desire to take responsibility for one's own life or problems at hand. Resilient individuals are proactive, not reactive, and are responsible for solving problems, always trying to improve themselves or situations that can be changed and increase their ability to deal with things that cannot be changed

a. Creativity

Creativity involves the ability to think of various options, consequences and alternatives in facing life's challenges. Resilient individuals do not engage in negative behavior because they are able to consider the consequences of each behavior and make correct decisions. Creativity also involves the power of imagination which is used to express oneself in art, as well as enabling a person to entertain himself when faced with difficulties.

b. Humor

Humor is the ability to see the bright side of life, laugh at oneself and find happiness in any situation. Resilient individuals use their sense of humor to view life's challenges in a new and lighter way.

c. Morality

Morality or orientation to values is characterized by the desire to live well and productively. Resilient individuals can evaluate various things and make the right decisions without fear of other people's opinions. They can also overcome selfinterest in helping others in need.

Basic Resilience Skills

According to Reivich and Shatte (2002), there are seven abilities that form resilience and almost no individual has these abilities well, which are as follows:

\section{a. Emotion Regulation}

Emotional regulation is the ability to remain calm under stressful conditions. The results showed that people who have the ability to regulate emotions have difficulty building and maintaining relationships with other people. The more isolated we are with anger, the more angry we become.

b. Reivich and Shatte (2002: 38) reveal two skills that can make it easier for individuals to conduct emotional regulation, namely calming and focusing. Individuals who are able to manage these two skills can help relieve existing emotions, focus disturbing thoughts and reduce stress experienced by individuals.

c. Impulse control

Impulse control is the individual's ability to control the desires, urges, likes and pressures that arise in a person. Individuals who have low selfcontrol abilities, quickly experience emotional changes which ultimately control their thoughts and behavior.

d. Optimism

Resilient individuals are individuals who are optimistic. Optimism is someone seeing that his future is bright and happy. Optimism possessed by an individual indicates that the individual believes that he has the ability to overcome adversities that may occur in the future. This also reflects an individual's self-efficacy, namely the individual's belief that he can solve existing problems and be able to control his life.

\section{e. Problem Cause Analysis}

Causal analysis is the ability of individuals to identify problems accurately from the problems they face. Selingman revealed a concept that is closely related to the analysis of the causes of the problem, namely explanatory thinking style. Explanatory thinking style is a way that is usually used by individuals to explain something good and bad that happens to him. The style of thinking with this method can be divided into three, namely:

\section{I - not me (personal)}

My style of thinking is an individual who tends to blame himself for the problems that befall him. Meanwhile, the "not me" style of thinking is 
emphasizing the other party who is the cause of the error.

\section{Always - not always (permanent)}

Someone who thinks "always" assumes that when a failure occurs there will be the next failure that accompanies it. This individual will always feel pessimistic. Meanwhile, optimistic individuals tend to see failure from the positive side and try to do better at every opportunity.

3.All - not all (pervasive)

The "all" thinking style views failure on one side of life as a cause for failure on the other side of life. Meanwhile, the "not all" style of thinking is able to explain the cause of a problem he is facing. According to Revich, K., \& Shatte, A. (2002) Resilient individuals will not blame others for the mistakes they have made in order to maintain their self-esteem or free them from guilt. They are not too focused on factors that are beyond their control, instead they are focused and in full control of problem solving, slowly they begin to solve existing problems, direct their lives, get up and achieve success.

a. Empathy

Empathy relates how individuals are able to read signs of other people's emotional and psychological conditions. Some individuals have the ability to interpret non-verbal languages shown by others, such as expressions

\section{Self Efficacy}

Self-efficacy (Revich, K., \& Shatte, A. 2002) is a belief that individuals are able to solve and deal with problems experienced effectively. Selfefficacy also means believing that you are capable, successful and successful. Individuals with high self-efficacy are committed to solving their problems and do not give up when they find that the strategies they are using are not working. Self-efficacy is the result of successful problem solving so that as individuals build success gradually in dealing with problems, self-efficacy will continue to increase. So that it becomes very important to achieve resilience.

b. Reaching out

As previously explained, resilience is not only an individual who has the ability to overcome adversity and rise from adversity, but more than that resilience is also the capacity of an individual to achieve the positive aspects of a downturn that occurs within him (Revich, K., \& Shatte, A. 2002).

\section{Conclusion}

The digital age is an age without borders for the flow of information across religions and countries. There are many advantages and positives from this digital era. Many things that are difficult become easy and the old ones become fast can all be done easily with the help of increasingly sophisticated technological tools. Responding to the many negative issues of today's changing times. This forgiveness applies to oneself as well as to others. Forgiving others will make life calmer and more peaceful while forgiving oneself makes life a qanaah and tawadhu '. Meanwhile, in an effort to practice forgiveness, we take several steps, namely remembering the pain we have, then empathizing with the perpetrator that he also feels the pain we have because in fact every soul longs for calm and peace in his life. The third step is to try to forgive his mistakes, then remain committed to giving forgiveness and finally survive to have the nature of forgiveness to anyone.

\section{References}

[1] Ali, S. 2017. "Forgiveness Model Profetik dalam Bandingan Struktural Teori Konflik".Analisis: Jurnal Studi Keislaman. Vol 14. No.1.

[2] Al-Mabuk, R. H., Enright, R. D., \& Cardis, P. A. 1995. Forgiveness Education With Parentally Love Deprived Late Adolescents. Journal of Moral Education.

[3] Al-Mahalli, I. J. 2009. Tafsir Jalalain. Jilid 1. B. A. Bakar, Penerj. Bandung: Sinar Baru Al-Gesindo.

[4] Cholidi, "Maghfirah," . 2008. dalam M. Quraish Shihab,et al.ed..Ensiklopedia AlQur'an: Kajian Kosa Kata, vol. III. Jakarta: Lentera Hati.

[5] Enright, R. D., \& Coyle, C. T. 1998. Researching the Process Model Of Forgiveness Within Psychological Interventions. Dimensions of forgiveness: Psychological research and theological 
perspectives.

[6] Enright, R. D., Subkoviak, M. J., Wu, C. R., Gassin, E. A., Freedman, S., Olson, L. M., \& Sarinopoulos, I. 1995. Measuring interpersonal forgiveness in late adolescence and middle adulthood. Journal of adolescence, Vol.18. No.6. .Forgiveness as human strength: Theory, Measurement, And Links To Well-Being.

[7] Freedman, S., Enright, R. D., \& Knutson, J. 2005. A progress report on the process model of forgiveness. Handbook of Forgiveness.

[8] Gerlach, T. M., Allemand, M., Agroskin, D., \& Denissen, J. J. 2012. Justice sensitivity and forgiveness in close interpersonal relationships: The mediating role of mistrustful, legitimizing, and prorelationship cognitions. Journal Of Personality.

[9] Ghuzairoh, T. 2015. Perbedaan forgiveness ditinjau dari jenis kelamin pada Budaya Jawa. Doctoral dissertation, Universitas Islam Negeri Maulana Malik Ibrahim.

[10] Klaus Krippendorff. 1991. Content Analysis; Introduction to Its Theory and Methodology. Diterjemahkan oleh Farid Wajidi. Jakarta: Rajawali PressKutubus Tis'ah. Kitab Hadits Digital.

[11] Macaskill, A., Maltby, J., \& Day, L. 2002. Forgiveness of self and others and emotional empathy. The Journal of social psychology. Vol. 145. No 5.

[12] Mahally, J., \& al-Suyuthy, J. A. R. Tafsir al-Jalalain. Cairo: Mathba'ah al-Sya'b, t. th, Al-Mahalli, I. J. 2009. Tafsir Jalalain Jilid 1. B. A. Bakar, Penerj. Bandung: Sinar Baru al-Gesindo.

[13] McCullough, M E., Root, Lindsey M., Cohen, Adam D. 2006. Writing About the Benefits of an Interpersonal Transgression Facilitates Forgiveness. Journal of Consulting and Clinical Psychology. Vol. 74. No. 4.

[14] McCullough, M. E. 2000. Forgiveness as human strength: Theory, measurement, and links to well-being. Journal of Social and Clinical Psychology. Vol. 19. No.1.

[15] McCullough, M. E., \& Witvliet, C. V. 2002. The psychology of forgiveness. Handbook of positive psychology.

[16] McCullough, M. E., Fincham, F. D., \& Tsang, J. A. 2003. Forgiveness, forbearance, and time: the temporal unfolding of transgression-related interpersonal motivations. Journal of personality and social psychology.

[17] McCullough, Michael E., Worthington, Everentt L., Rachal, Kenneth. 1997. Interpersonal Forgiving in Close Relationships. Journal of Personality and Social Psychology.

[18] Moleong, L.J. 1996. Metodologi Penelitian Kualitatif. Bandung: Penerbit PT. Remaja Rosdakarya.

[19] Fuas Ábdul Baqi, Muhammad 1428H/2007M Mu'jam Mufahras li Alfazh Al-Qurán al- Karim, al:Qahirah, Dar al Hadits,.

[20] Syafi" i Antonio. 2009. Muhammad Asma" ul Husna For Success in Business \& LifeJakarta: Tazkia Publishing.

[21] Park, J. H., Enright, R. D., Essex, M. J., Zahn-Waxler, C., \& Klatt, J. S. 2013. Forgiveness intervention for female South Korean adolescent aggressive victims. Journal of Applied Developmental Psychology. Vol. 34. No. 6.

[22] Philpot, C. R., \& Hornsey, M. J. 2011. Memory for intergroup apologies and its relationship with forgiveness. European Journal of Social Psychology.Vol. 41. No. 1.

[23] Hati. Rahmandani, A., \& Subandi, M. A. 2017. Pengaruh Terapi Pemaafan dalam Meningkatkan Penerimaan Diri Penderita Kanker Payudara. JIP: Jurnal Intervensi Psikologi. Vol. 2. No.2.

[24] Setiyana, V. Y. 2013. Forgiveness dan stres kerja terhadap perawat. Jurnal ilmiah Psikologi Terapan. Vol. 23. No. 3. 
[25] Snyder, C. R., \& Lopez, S. J. 2009. Oxford handbook of positive psychology. Oxford University Press, USA.

[26] Tangney, J. P., Boone, A. L., \& Dearing, R. 2005. Forgiving the self: Conceptual issues and empirical findings. Handbook of forgiveness.

[27] Walton, E. 2005. Therapeutic forgiveness: Developing a model for empowering victims of sexual abuse. Clinical Social Work Journal, Vol. 33. No. 2.

[28] Worthington Jr, E. L. 1998. The pyramid model of forgiveness: Some interdisciplinary speculations about unforgiveness and the promotion of forgiveness. Dimensions of forgiveness: Psychological research and theological perspectives.

[29] Worthington Jr, E. L. 2006. Forgiveness and reconciliation: Theory and application.Routledge.

[30] Worthington, E. L., \& Scherer, M. 2004. Forgiveness is an emotion-focused coping strategy that can reduce health risks and promote health resilience: Theory, review, and hypotheses. Psychology \& Health. 